\title{
PENGOLAHAN LIMBAH RUMAH TANGGA (AIR LERI) MENJADI PUPUK ORGANIK CAIR (POCA) DI KABUPATEN PROBOLINGGO
}

\author{
Linda Kurnia Supraptiningsih $^{1)}$, Rofikha Nuriyanti ${ }^{2)}$, Adi Sutrisno ${ }^{3)}$ \\ linda.kurnia@upm.ac.id ${ }^{1)}$ \\ Fakultas Teknik Universitas Panca Marga Probolinggo ${ }^{1)}$
}

\begin{abstract}
ABSTRAK
Tujuan dari kegiatan ini adalah melakukan pembinaan kepada mitra yaitu kelompok PKK Desa Lambangkuning Kecamatan Lumbang Kabupaten Probolinggo. Ibu-ibu di Desa Lambangkuning banyak yang masih menganggur dan masih bergantung dari pendapatan suami sehingga diperlukan penghasilan tambahan untuk menyokong kehidupan mereka sehari-hari. Melihat situasi ini, salah satu upaya untuk dapat membantu menyelesaikan permasalahan mitra adalah memberikan pelatihan pengolahan limbah air leri menjadi pupuk organik cair $(P O C a)$ yang tentunya selain ramah lingkungan juga memiliki nilai jual. Solusi konkrit yang dilakukan pengusul untuk mengatasi permasalahan yaitu dengan membuat model mesin pencacah daun Paitan (bahan tambahan pembuatan pupuk), solusi selanjutnya yang perlu ditambahkan adalah dengan membuatkan akun marketplace Bukalapak dengan sarana berupa jaringan internet atau indihome untuk menambah jangkauan pemasaran. Terakhir melakukan sosialisasi pemanfaatan bahan limbah menjadi barang bernilai ekonomi.
\end{abstract}

Kata Kunci: limbah air leri, mesin pencacah daun, marketplace.

\section{PENDAHULUAN}

Dewasa ini pada umumnya kondisi lahan pertanian di Indonesia mengalami kemunduran kesuburan dan kerusakan tanah serta telah mengalami penurunan produktivitas. Penyebabnya diantaranya adalah: a) ketidakseimbangan kadar hara dalam tanah; b) pengurasan dan defisit hara; c) penurunan kadar bahan organik tanah; d) pendangkalan lapisan tapak bajak; e) pencemaran oleh bahan agrokimia atau limbah; f) penurunan populasi dan aktivitas mikroba; dan g) salinisasi/alkalinisasi(Hartatik, dkk. 2015).

Akibat pengelolaan hara yang kurang bijaksana, sebagian besar lahan sawah terindikasi berkadar bahan organik sangat rendah (C-organik <2\%). Sekitar $65 \%$ dari 7,9 juta ha lahan sawah di Indonesia memiliki kandungan bahan organik rendah sampai sangat rendah (C-organik <2\%), sekitar $17 \%$ mempunyai kadar 
total $\mathrm{P}$ tanah yang rendah dan sekitar $12 \%$ berkadar total $\mathrm{K}$ rendah (Kasno, dkk. 2003). Untuk mengurangi kemunduran kesuburan tanah akibat pemakaian pupuk kimia secara terus menerus dan meningkatkan produktivitas hasil pertanian perlu pemanfaatan pupuk organik yang memadai baik dalam jumlah, kualitas dan kontinuitasnya. Pupuk organik saat ini sudah banyak dikenal masyarakat bahkan menjadi program pemerintah untuk meningkatkan kesuburan dan produksi tanaman.

Pupuk organik cair limbah rumah tangga seperti limbah cucian beras dapat dijadikan sebagai pupuk organik pada tanaman. Pupuk organik cair selain dapat meningkatkan kesuburan tanah juga dapat meningkatkan kesehatan lingkungan. Limbah air cucian beras merupakan hasil buangan yang berasal dari suatu proses produksi baik industri maupun domestik (rumah tangga) yang tidak memiliki nilai ekonomis lagi. Air cucian beras mengandung banya nutrisi diantaranya adalah karbohidrat, nitrogen, fosfor, kalium, magnesium, sulfur, besi, Vitamin $\mathrm{B}_{1}$ (Wulandari, dkk. 2012).

Dalam pengolahannya menjadi nasi, beras mengalami proses pencucian sebelum dimasak. Pada proses pencucian beras biasanya dicuci atau dibilas sebanyak 3 kali sebagai upaya untuk membersihkan beras dari kotoran. Air cucian beras atau sering disebut sebagai leri (bahasa Jawa) berwarna putih susu, hal itu berarti bahwa protein dan vitamin $B_{1}$ yang banyak terdapat dalam beras juga ikut terkikis. Secara tidak langsung protein dan vitamin $B_{1}$ banyak terkandung di dalam air leri atau air cucian beras. Vitamin B $_{1}$ merupakan kelompok vitamin B yang mempunyai peranan penting dalam proses metabolisme tanaman dalam hal mengkonversikan karbohidrat menjadi energi untuk menggerakkan aktifitas di dalam tubuh tanaman. Air leri atau air bekas cucian beras dapat merangsang pertumbuhan akar tanaman Adenium. Hal tersebut disebabkan karena air cucian beras mengandung vitamin $B_{1}$ yang berfungsi merangsang pertumbuhan serta metabolisme akar (Andrianto, 2007). Salah satu kandungan leri adalah fosfor yang merupakan unsur hara makro yang sangat dibutuhkan oleh tanaman. Lebih lanjut pemberian air leri memberikan pengaruh nyata terhadap lebar tudung maksimal buah jamur tiram putih (Kalsum, dkk. 2011). 
Desa Lambangkuning terletak di Kecamatan Lumbang Kabupaten Probolinggo yang terdiri dari 3 Dusun yaitu Dusun Krajan, Dusun Kesut dan Dusun Sentono, 3 RW dan 14 RT. Wilayah Desa Lambangkuning merupakan daerah dataran tinggi karena letaknya berada di ketinggian kurang lebih 500 mdpl. Lahan pertanian di Desa Lambangkuning merupakan ladang atau sawah tadah hujan yang pada musim kemarau tidak memungkinkan adanya aktivitas pertanian. Pendapatan perkapita di Desa Lambangkuning tergolong rendah jika dibandingkan dengan desa lain di Kecamatan Lumbang karena mayoritas mata pencaharian masyarakatnya adalah buruh kasar yang jika pada musim hujan adalah petani atau bisa disebut juga petani musiman. Ibu-ibu di Desa Lambangkuning sebagian besar tidak bekerja dan hanya menjadi ibu rumah tangga yang sepenuhnya bergantung pada pendapatan suami saja.

Gerakan PKK bertujuan memberdayakan keluarga untuk meningkatkan kesejahteraan menuju terwujudnya keluarga sehat sejahtera, maju dan mandiri serta sadar lingkungan. Di Desa Lambangkuning terdapat kelompok ibu-ibu PKK yang berjumlah kurang lebih 30 orang yang diketuai oleh Ibu Sunanti. Kegiatan PKK di Desa Lambangkuning sudah cukup aktif berjalan karena sudah ada pertemuan-pertemuan rutin setiap bulannya diantaranya adalah kegiatan posyandu, penyuluhan kesehatan dan pelatihan keterampilan seperti praktek memasak, membuat kerajinan tangan dan lain sebagainya.

Hasil survey awal tim pelaksana diperoleh data bahwa setiap rumah tangga di desa Lambangkuning dipastikan memasak nasi setiap harinya. Dalam sehari setiap rumah tangga rata-rata memasak sebanyak 1 kali yaitu setiap pagi dengan kuantitas kurang lebih 5 liter air leri dihasilkan karena idelanya mencuci beras tidak perlu terlalu bersih mengingat nilai nutrisi yang akan ikut terbuang bersama air bilasan. Anggota dan pengurus PKK di Desa Lambangkuning berjumlah 30 orang, jadi dalam sehari limbah air cucian beras yang dihasilkan oleh ibu-ibu PKK sejumlah kurang lebih 150 liter.

Berdasarkan uraian diatas, tim pelaksana ingin mencoba memberikan solusi untuk mengatasi permasalahan ekonomi yang dialami Desa Lambangkuning diantaranya adalah dengan mengadakan pelatihan pemanfaatan 
limbah air leri menjadi Pupuk Organik Cair (POCa). Pemanfaatan limbah air leri ini diharapkan mampu menyerap tenaga kerja khususnya para ibu-ibu PKK di lingkungan sekitar yang masih belum mempunyai pekerjaan tetap. Sehingga secara tidak langsung hal ini merupakan upaya menciptakan lingkungan kerja bagi ibu-ibu rumah tangga yang sebelumnya hanya mengandalkan penghasilan suami. Solusi ini juga dinilai sangat menguntungkan warga sekitar karena awalnya air sisa cucian beras dibuang begitu saja diolah menjadi barang yang mempunyai nilai jual sehingga mampu meningkatkan pendapatan mereka. Selain itu manfaat yang paling penting dari pengolahan limbah air leri menjadi POCa adalah terciptanya lingkungan yang sehat karena dampak dari pemakaian pupuk kimia dapat diminimalisir.

\section{METODE PELAKSANAAN}

Permasalahan yang sudah diidentifikasi dan disimpulkan akan dicari solusinya dengan pendekatan yang tepat sehingga permasalahan yang telah dipaparkan dapat teratasi dengan baik. Tahapan-tahapan yang harus dilalui untuk mencapai solusi yaitu:

\section{a. Diskusi dan Pengumpulan Referensi}

Diskusi antara tim pelaksana dengan mitra tentang solusi permasalahan yang ada. Mengumpulkan referensi tentang pembuatan mesin pencacah daun. Mengumpulkan referensi tentang model-model pemasaran online dalam bentuk situs marketplace yang akan digunakan oleh mitra sebagai pelaku usaha.

b. Merancang mesin pencacah rumput dan mendesain marketplace Bukalapak yang akan digunakan oleh mitra.

c. Uji Coba Mesin dan Marketplace.

Melakukan uji coba coba mesin pencacah daun apakah sudah berfungsi dengan baik, dilihat dari bentuk cacahan rata atau tidak. Menguji coba apakah situs marketplace Bukalapak yang sudah dibuat berfungsi dan mendapat respon positif dari masyarakat atau calon konsumen 
d. Melaksanakan Sosialisasi Pemanfaatan Bahan Limbah menjadi Barang bernilai Ekonomi.

Memberi pengetahuan kepada mitra mengenai pemanfaatan bahan limbah yag ada di sekitar kita. Sosialisasi ini bertujuan untuk memberi pengetahuan kepada mitra bahwa limbah yang ada di sekitar kita akan bernilai jual jika dimanfaatkan dengan cara bijaksana.

Beberapa tahapan di atas merupakan tahapan untuk mencapai solusi terbaik dari permasalahan prioritas yang disepakati bersama mitra. Solusi tersebut yaitu:

a) Mesin Pencacah Daun dengan spesifikasi sebagai berikut:

1) Dimensi : $800 \times 500 \times 800 \mathrm{~cm}$

2) Body : Pelat Besi Plattezer

3) Rangka : Besi Siku

4) Penggerak : Motor Diesel $8 \mathrm{Pk}$

5) Pisau : Baja

6) Kapasitas : $100-200 \mathrm{Kg} / \mathrm{jam}$

b) Marketplace Bukalapak untuk jangkauan pemasaran produk lebih luas Kelebihan Marketplace Bukalapak:

1) Usability : Tinggi

2) Sistem Navigasi : : Mudah dipahami pengunjung

3) Desain Grafis : : Menarik pengunjung

4) Content : Perbaruan berkala

5) Kompatibilitas Gawai : Adroid/IOS dan browser PC

6) Functionally : : Pemesanan produk bisa lewat akun pengguna masing-masing

\section{HASIL DAN PEMBAHAAN}

Pelaksanaan kegiatan Program Kemitraan Masyarakat (PKM) dengan judul PKM Pengolahan Limbah Rumah tangga (Air Leri) Menjadi POCa Oleh Ibu-Ibu PKK di Desa Lambangkuning Kecamatan Lumbang Kabupaten Probolinggo. Kegiatan program ini dipastikan diterima proposalnya dan tanda 
tangan kontrak dengan DRPM Kemenristekdikti melalui LPPM UPM Probolinggo. Tim pelaksana tediri dari satu ketua tim dan dua anggota tim yang dibantu oleh dua mahasiswa sebagai pembantu lapangan. Adapun kegiatan yang telah dilakukan sebagai berikut:

1) Diskusi dan Pengumpulan Referensi

Diskusi antara tim pelaksana dengan mitra tentang solusi permasalahan yang ada. Mengumpulkan referensi tentang pembuatan mesin pencacah daun dan model-model pemasaran online dalam bentuk marketplace yang akan digunakan oleh mitra.

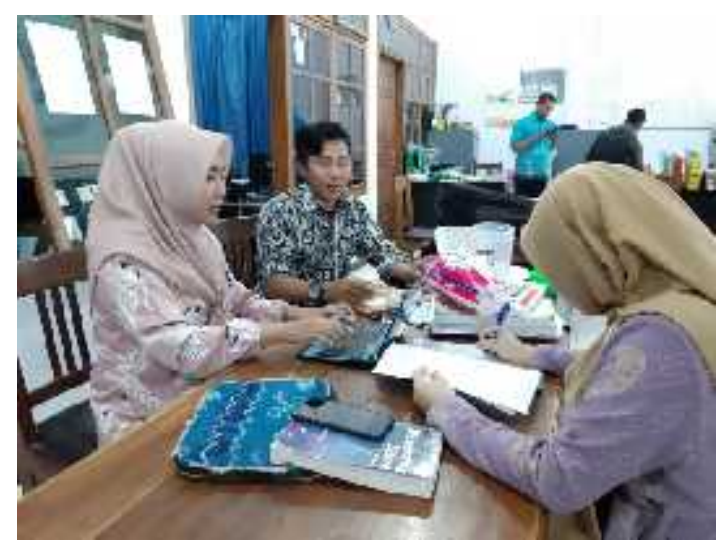

2) Pembuatan Mesin Pencacah Daun dan Konsep Marketplace.

Membuat mesin pencacah daun dan konsep halaman utama Bukalapak yang akan digunakan oleh mitra.
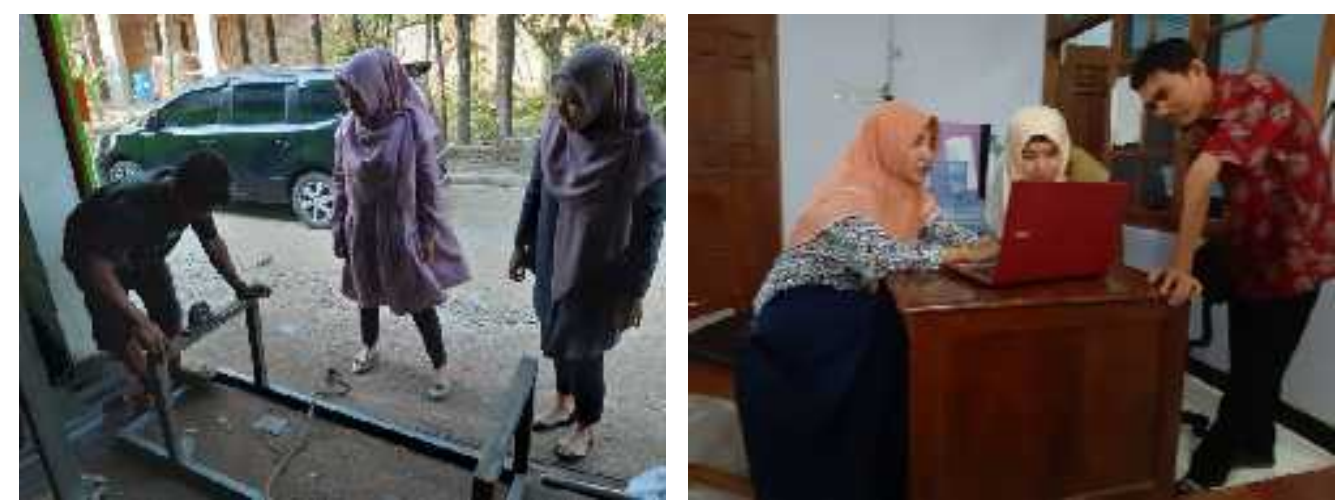

Gambar 2. Proses Pembuatan Mesin Pencacah Daun dan Finalisasi Konsep Halaman Bukalapak

3) Uji Coba Mesin Pencacah Daun

Menguji coba mesin pencacah daun, melakukan pengecekan kemampuan dalam mencacah dilihat dari tingkat kehalusan hasil cacahan. 


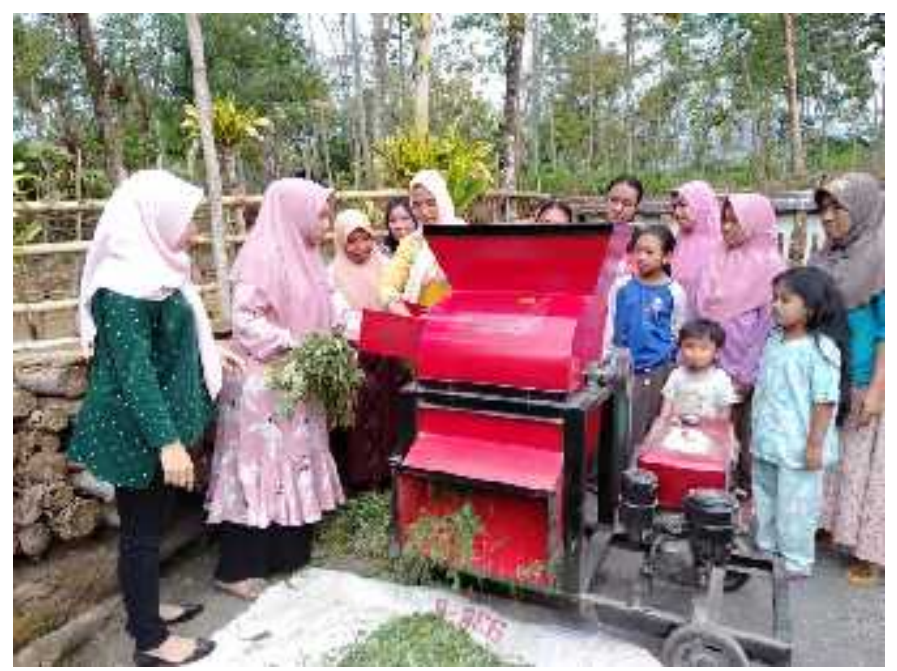

Gambar 3. Proses Uji Coba Mesin Pencacah Daun

4) Pelatihan pengoperasian mesin pencacah daun dan pengolahan limbah air leri menjadi $P O C a$

5) Sosialisasi pemanfaatan bahan limbah menjadi barang bernilai ekonomi bagi ibu-ibu di Desa Lambangkuning.

6) Evaluasi dan keberlanjutan pelaksanaan Program Kemitraan Masyarakat (PKM)

Mesin pencacah daun diserahkan kepada mitra, dan pelaksanaan kegiatan yang lainnya dilakukan monitoring dan evaluasi yang bertujuan untuk mengetahui apakah mesin tersebut berfungsi dengan baik dan dapat bermanfaat dalam jangka panjang. Sedangkan untuk monitoring di laksanakan secara berkala 1-2 bulan selama satu tahun ke depan. Untuk selanjutnya, diharapkan penggunaan mesin pencacah daun sebagai sarana dalam mengolah limbah rumah tangga menjadi POCa dapat digunakan dengan baik dan memberikan manfaat secara financial bagi ibu-ibu PKK Desa Lambangkuning.

Manfaat mesin pencacah daun adalah mempercepat proses pencacahan bahan baku dalam proses produksi POCa yakni selain menggunakan limbah air leru maka ditambahkan daun Paitan atau dalam bahasa latin disebut Tithonia. Kegiatan pelatihan yang dilakukan merupakan usaha dalam monitoring dan evaluasi efisiensi mesin pencacah daun. Dengan adanya pelatihan ini mitra dapat 
memperoleh pengetahuan tentang perawatan dan penggunaan mesin secara efektif dan efisien dalam jangka waktu yang panjang.

Produk-produk yang sudah dicapai dan dimanfaatkan oleh mitra mempunyai keunggulan dan kelemahan masing-masing. Mesin pencacah daun mempunyai keunggulan mencacah daun tanpa bantuan tangan manusia sehingga dapat lebih efisien, kelemahannya yaitu memerlukan tenaga yang relatif besar dalam menghidupkannya jadi tidak semua orang bisa menghidupkan mesin tersebut terutama ibu-ibu. Marketplace mempunyai keunggulan dapat memasarkan lebih efektif dalam jaringan/internet sehingga produk dapat dilihat seluruh dunia. Kelemahannya karena teknologi ini masih tergolong baru bagi ibuibu anggota PKK Desa Lambangkuning jadi masih perlu bimbingan dari tim secara berkelanjutan dalam mengelola "toko" online tersebut.

Paparan di atas menunjukan bahwa limbah rumah tangga mempunyai manfaat sangat baik jika diolah dengan bijak. Selain mengurangi pemakaian pupuk kimia yang lama kelamaan bisa merusak lingkungan dampak positif utamanya adalah menghasilkan pupuk organik yang tetntunya mempunyai nilai ekonomi.

\section{KESIMPULAN DAN SARAN}

\section{Kesimpulan}

Berdasarkan hasil pelaksanaan dan evaluasi kegiatan masyarakat yang berjudul "PKM Pengolahan Limbah Rumah tangga (Air Leri) Menjadi POCa Oleh Ibu-ibu PKK di Desa Lambangkuning Kecamatan Lumbang Kabupaten Probolinggo" dapat disimpulkan bahwa mesin pencacah daun yang telah di serahkan kepada mitra bekerja dengan baik sesuai dengan fungsinya. Pelatihan pembuatan POCa sangat bermanfaat karena membantu meningkatkan pengetahuan, kreatifitas, dan perekonomian mitra. Mitra sudah mulai memahami cara menggunakan marketplace Bukalapak dengan baik. Pengetahuan mitra menjadi bertambah setelah diadakannya sosialisasi mengenai pemanfatan bahan limbah menjadi barang bernilai ekonomi sehingga mitra menjadi tahu mana 
limbah yang bisa diolah kembali dan dijual. Hal tersebut akan meminimalisasi jumlah limbah di lingkungan sekitar.

\section{Saran}

Saran yang dapat diberikan sebagai masukan untuk kegiatan pengabdian berikutnya adalah

1. Penambahan bahan baku produk POCa.

2. Melakukan pengkajian secara rinci mengenai kandungan bahan baku dan manfaat tiap nutrisi yang ada dalam produk POCa.

3. Melibatkan pihak yang kompeten di bidang pertanian agar mutu dan kualitas produk $P O C a$ lebih baik lagi.

4. Melakukan pendaftaran pada HKI agar $P O C a$ tidak dapat diduplikasi oleh pihak lain.

\section{DAFTAR PUSTAKA}

Hartatik, dkk. 2015. Peranan Pupuk Organik dalam Peningkatan Produktivitas Tanah dan Tanaman. Jurnal Sumberdaya Lahan. 9(2): 107-120.

Kasno, A., D. Setyorini, dan Nurjaya. 2003. Status C-organik Lahan Sawah di Indonesia. Dalam Prosiding Himpunan Ilmu Tanah Indonesia, Universitas Andalas, Padang.

Wulandari, G.M. Citra, dkk. 2012. Pengaruh Air Cucian Beras Merah dan Beras Putih Terhadap Pertumbuhan dan Hasil Selada (Lactuca sativa L.). Jurnal Vegetalica (online). 1(2). Diakses tanggal 11 Oktober 2018.

Andrianto, H. 2007. Pengaruh air cucian beras pada Adenium. Skripsi Fakultas Keguruan dan Ilmu Pendidikan Universitas Muhamadiyah Surakarta. (online). Diakses tanggal 27 Sepember 2018.

Kalsum, dkk. 2011. Efektivitas Pemberian Air Leri terhadap Pertumbuhan dan Hasil Jamur Tiram Putih (Pleurotus Ostreatus). Jurnal Agrovigor. 4(2): 86-92. 